\title{
Comparison of neutral proteinase activities in cock and ram spermatozoa and observations on a proacrosin in cock spermatozoa
}

\author{
C. R. Brown and E. F. Hartree \\ A.R.C. Unit of Reproductive Physiology and Biochemistry, University of Cambridge, U.K.*
}

\begin{abstract}
Summary. Cock spermatozoa, like trypsin, induced a rapid fall in the viscosity of gelatin solutions but ram spermatozoa and inhibitor-free ram acrosin were ineffective. The gelatin-hydrolysing activity in cock spermatozoa was solubilized at $\mathrm{pH} 8$ in the presence of calcium ions but comparable extracts of ram spermatozoa were inactive. Both extracts showed acrosin activity (assayed with benzoylarginine ethyl ester). The two catalytic activities of cock spermatozoa were each susceptible to the same trypsin inhibitors and during fractionations they were not separable. We deduce that cock acrosin, and probably some other avian acrosins, have the power to degrade dissolved gelatin while ram acrosin does not. The acrosin in cock spermatozoa, unlike that in ram spermatozoa, was inactivated at $\mathbf{p H ~ 2 \cdot 7 . ~ A c i d ~ e x t r a c t s ~ o f ~ t h e ~ f o r m e r ~ c o n t a i n ~ a n ~}$ inactive precursor of acrosin which undergoes spontaneous re-activation in buffers, $\mathrm{pH} 8$, containing calcium ions. In this respect it resembles the proacrosin of rabbit testis.
\end{abstract}

\section{Introduction}

Our investigation began as an attempt to throw light on observations by Buruiana (1956) on the 'trypsin' activities of semen. He found that, with few exceptions, mammalian semen showed no neutral proteinase activity whereas avian semen usually showed marked activity. Nevertheless Buruiana's paper has been cited by authors of numerous papers dealing with proteinases of mammalian spermatozoa as an early pointer to the presence in such spermatozoa of a trypsin-like enzyme and, by implication, of acrosin. It may be deduced from Buruiana's (1956) paper that he used a protein as substrate for his trypsin assay, but the assay procedure and the nature of the protein were published only in Romanian, and so have remained inaccessible.

Extracts of cock spermatozoa are known to hydrolyse benzoylarginine-2-naphthylamide (Ho \& Meizel, 1970a) and benzoylarginine ethyl ester (Zaneveld, Polakoski \& Williams, 1973) at pH 8; also, the former reaction is inhibited by soy-bean trypsin inhibitor and by cock seminal plasma (Ho \& Meizel, 1970a, b). Cock spermatozoa thus contain an enzyme having some essential properties of acrosin. This paper reports investigations on this enzyme and also provides evidence for a cock proacrosin.

\section{Materials and Methods}

Semen, usually 2-3 ml, was obtained by massage from cocks in a colony of inbred White Leghorns. Ram semen was obtained by artificial vagina (Brown, Andani \& Hartree, 1975a). Cell counts were made with a haemocytometer.

Ovomucoid (type II-0) and $N_{\alpha}$-benzoyl-L-arginine ethyl ester hydrochloride (BAEE) were from Sigma Chemical Co., Kingston-upon-Thames KT2 7BH; diisopropylfluorophosphate (DFP) and gelatin (powder) were from B.D.H. Chemicals Ltd, Poole BH12 4NN. Other reagents were from

* Postal address: Animal Research Station, 307 Huntingdon Road, Cambridge CB3 0JQ, U.K. 
sources specified by Brown et al. (1975a), who also describe the isolation of inhibitor-free ram acrosin and of ram acrosomal inhibitor (an inhibitor of acrosin and trypsin).

\section{Fractionation of semen and solubilization of acrosin}

Procedures are described in Flow-sheet 1. After separation of seminal plasma from spermatozoa the latter were processed to yield clear extracts (Fractions 1, 2, 3). Soluble ram acrosin can be obtained in near-quantitative yield by extracting denuded spermatozoa, or frozen-thawed spermatozoa, (i) at pH 2.7 (Brown \& Hartree, 1974), or (ii) at pH 8 in the presence of $\mathrm{CaCl}_{2}$. Only the latter procedure was successful with cock spermatozoa. To obtain a $\mathrm{Ca}^{2+}$-free solution of cock acrosin (Fraction 3) an extract containing $\mathrm{CaCl}_{2}$ was dialysed against a solution of benzamidine (an acrosin inhibitor) and then, briefly, against a tris buffer to remove benzamidine.

The quantity of a sperm fraction taken for assay is expressed as sperm equivalent (s.e.). This represents either the millions of spermatozoa used in an assay or the millions from which was derived the volume of a fraction taken for assay. Trypsin and acrosin were used as solutions in $1 \mathrm{~mm}-\mathrm{HCl}$.

Flow-sheet 1. Fractionations of semen. 'Sucrose' denotes a $0.25 \mathrm{M}$ solution; 'buffer' denotes 25 mm-tris$\mathrm{HCl}$, pH 8.0. During Treatments $1-3$ the temperature was $0-5^{\circ} \mathrm{C}$ and centrifugation was at $25,000 \mathrm{~g}$ for $15 \mathrm{~min}$.

A. COCK SEMEN $(2 \mathrm{ml})$

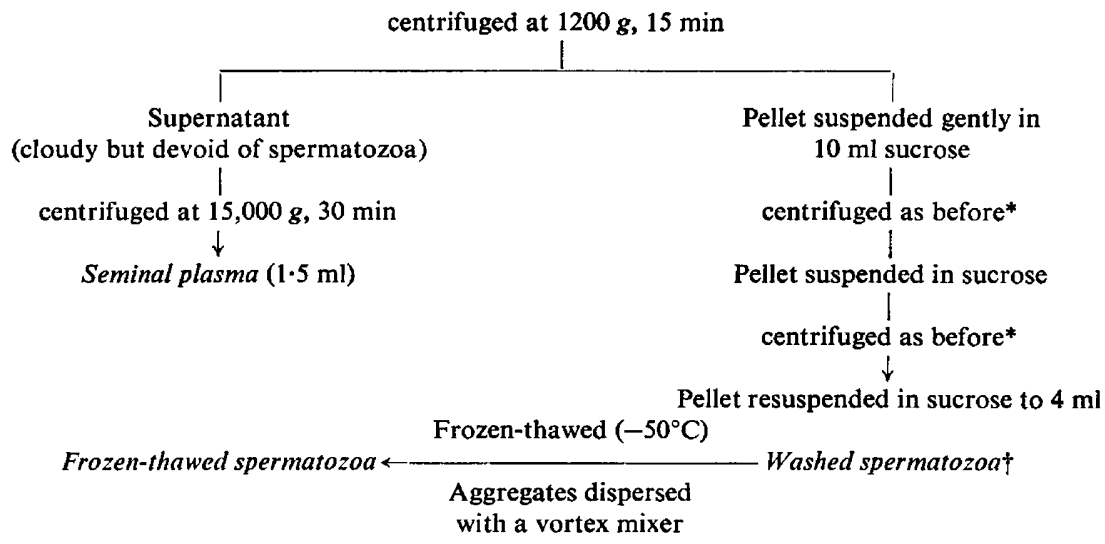

Batches of frozen-thawed spermatozoa were treated as follows.

(1) The suspension was acidified to $\mathrm{pH} 2.7$ with $1 \mathrm{M}-\mathrm{HCl}$. After centrifugation for 15 min supernatant Fraction 1 was collected. The pellet material was washed with sucrose and resuspended in sucrose (Fraction IP).

(2) The suspension was diluted with $1.5 \mathrm{vol}$ sucrose and 0.5 vol buffer containing $1 \mathrm{M}-\mathrm{CaCl}_{2}$. After centrifugation for $15 \mathrm{~min}$ the clear Fraction 2 was collected.

(3) Fraction 2 was dialysed ( $24 \mathrm{hr}$ ) against two lots of buffer containing $5 \mathrm{~mm}$-benzamidine, then for $6 \mathrm{hr}$ against buffer to yield Fraction 3 .

\section{B. RAM SEMEN}

This was fractionated as described by Brown et al. (1975a) to yield seminal plasma, washed spermatozoa and 'denuded' spermatozoa. The last-named are frozen-thawed spermatozoa which have been freed from the acrosomal material that becomes detached as a result of freezing. They were used to prepare a Fraction 2 (as above). $3000 \mathrm{~g}$.

* The supernatant fluids were devoid of acrosin activity after residual spermatozoa had been sedimented at

$\uparrow$ For the experiments of Table 4, the $4 \mathrm{ml}$ washed spermatozoa were from $3 \cdot 3 \mathrm{ml}$ of semen. 
Enzyme and inhibitor assays with synthetic substrates

Activities of acrosin and trypsin were measured at $\mathrm{pH} 8$ in a pH-stat (Brown et al., 1975a). The assay was in a final volume of $1.6 \mathrm{ml}$ which contained enzyme, $5 \mathrm{~mm}$-tris- $\mathrm{HCl}, 0.2 \mathrm{M}-\mathrm{CaCl}_{2}$, inhibitor (where specified) and $2 \mathrm{~mm}$-BAEE. In the standard procedure BAEE (as a $10 \mathrm{~mm}$ aqueous solution) was added after other components had been in contact for $10 \mathrm{~min}$. This allowed time for the reaction of enzyme with inhibitor.

Enzyme units $(\mathrm{U})$ are $\mu \mathrm{mol}$ BAEE hydrolysed $/ \mathrm{min}$, and $\mathrm{U} / \mathrm{ml}$ semen denotes units in the quantity of fraction derived from $1 \mathrm{ml}$ of semen.

The molarity of solutions of trypsin and ram acrosin was assayed by a fluorimetric method which gives concentrations in terms of active sites (Brown et al., 1975b). The total molarity of acrosin inhibitors in seminal plasma was determined as in Fig. 9 of Brown et al. (1975a) using tris- $\mathrm{HCl}$ buffer and a known molar quantity of acrosin.

\section{Viscometric method for following proteolysis of gelatin}

Preparation of gelatin solution (procedure of Buruiană \& Niculescu, 1957). A suspension of $20 \mathrm{~g}$ gelatin powder in $500 \mathrm{ml} 4 \mathrm{~mm}$-acetic acid was shaken occasionally during $8 \mathrm{hr}$ and transferred to a measuring cylinder. Next day the clear fluid was drawn off and the gelatin was washed four times by suspending it in water and decanting the water $1 \mathrm{hr}$ later. The swollen gelatin was heated on a boiling water-bath with $400 \mathrm{ml} 15 \mathrm{~mm}-\mathrm{Na}_{2} \mathrm{HPO}_{4}$ to obtain a clear solution. After addition of a few crystals of thymol, the $\mathrm{pH}$ of the warm solution was adjusted to 7.6 with $1 \mathrm{M}-\mathrm{NaOH}$. Ten $\mathrm{ml}$ portions were put into test-tubes which were capped with Parafilm and stored at $5^{\circ} \mathrm{C}$.

Other gelatin solutions. These were prepared at the same concentration and $\mathrm{pH}$ as above but in (i) $50 \mathrm{~mm}$-tris- $\mathrm{HCl}$, (ii) tris- $\mathrm{HCl}$ containing $0 \cdot 2 \mathrm{M}-\mathrm{CaCl}_{2}$, (iii) $0 \cdot 1 \mathrm{M}$-sodium barbiturate-acetic acid. Unless otherwise stated viscometric experiments were run in phosphate-gelatin.

Determination of relative viscosity. Ostwald viscometers were set up in a thermostat at $37 \pm 0.02^{\circ} \mathrm{C}$. Standard viscometers have flow-times for gelatin solution which exceed $1.5 \mathrm{~min}$. Therefore, to follow rapid changes in viscosity we used a non-standard viscometer which had a flow-volume of $3.5 \mathrm{ml}$ and a flow-time of $15-18 \mathrm{sec}$ with phosphate-gelatin.

The relative viscosity $(\eta)$ of stock gelatin solutions (i.e. relative to water) was determined in a standard viscometer. For phosphate-gelatin the range of $\eta$ was $4 \cdot 0-4 \cdot 6$. Solutions of gelatin in other buffers exhibited lower values. For convenience the symbol $\eta$ is used instead of the customary $\eta_{\text {rel }}$.

Assay procedure (see also Northrop \& Kunitz, 1933; Buruiană, Gluhovschi, Bilcea \& Năfornită, 1956). Tubes containing gelatin were warmed to $37^{\circ} \mathrm{C}$ and one was used to determine the flow-time in the rapid-flow viscometer. Another tube received enzyme (usually not more than $0.2 \mathrm{ml}$ ), its contents were mixed by inversion and transferred immediately to the viscometer. Flow-times were measured at appropriate intervals (see Text-fig. 1) and converted to $\eta$ values. In each series was included a gelatin tube with $50 \mu \mathrm{g}$ crystalline bovine trypsin. This caused the flow-time to decrease, within $20 \mathrm{~min}$, to a constant value from which $\eta_{\infty}$ ( $\eta$ for completely degraded gelatin) could be calculated.

To determine effects of inhibitors, the enzyme and inhibitor were mixed in a small volume at $\mathrm{pH} 7.6$ (or in $0.25 \mathrm{M}$-sucrose if spermatozoa were used as enzyme), stored for $10 \mathrm{~min}$ and an aliquot was taken for viscometric assay. The inhibitor-free control assays also involved a 10 -min storage period.

\section{Kinetics of proteolysis of gelatin}

The progress of a first-order enzyme reaction is expressed by

$$
k[E]=\frac{2 \cdot 3}{t} \log \frac{a_{0}}{a_{t}}
$$

where $a_{0}$ is the initial substrate concentration, $a_{t}$ is the concentration at time $t,[E]$ is the concentration of enzyme and $k$ is the velocity constant. If the relative viscosity of gelatin be taken as a measure 
of substrate concentration the initial concentration may be represented as $\left(\eta_{0}-\eta_{\infty}\right)$ and the concentration at time $\mathrm{t}$ as $\left(\eta_{\mathrm{t}}-\eta_{\infty}\right)$. When [E] is fixed $k[\mathrm{E}]$ can be replaced by another constant, $k^{\prime}$. Rearranging Equation 1 and making these substitutions gives

$$
\log \left(\eta_{t}-\eta_{\infty}\right)=\log \left(\eta_{0}-\eta_{\infty}\right)-\frac{t k^{\prime}}{2 \cdot 3}
$$

Since the second $\log$ term is a constant for a given solution of gelatin it follows that a plot of $\log \left(\eta_{t}-\eta_{\infty}\right)$ against $t$ would be a straight line with a slope of $-k^{\prime} / 2 \cdot 3$.

Cleavage of a few peptide bonds in a protein, to yield peptide fragments, will cause a much larger arithmetic decrease in the viscosity of its solution than will subsequent hydrolysis of the same number of bonds in the peptide mixture. Thus strictly linear plots of $\log \left(\eta_{t}-\eta_{\infty}\right)$ against time cannot be expected. Nevertheless this form of presentation has advantages in that a progress curve usually has regions of linearity for which $k^{\prime}$ may be calculated.

\section{Results}

\section{Hydrolysis of gelatin: catalysis by trypsin and lack of catalysis by ram spermatozoa}

Addition of $50 \mu \mathrm{g}$ bovine trypsin to gelatin solution caused a rapid fall in viscosity but addition of frozen-thawed ram spermatozoa, which contain acrosin inhibitor, caused no measurable change during $15 \mathrm{~min}$ (Text-fig. 1). Addition of trypsin $15 \mathrm{~min}$ after frozen-thawed ram spermatozoa initiated hydrolysis of gelatin at rates nearly as great as those obtained when only trypsin was added. Denuded ram spermatozoa, which contain only traces of acrosin inhibitor (Brown et al., 1975a), were inactive as were also whole ram semen and seminal plasma. Convincing evidence that ram acrosin cannot catalyse hydrolysis of gelatin was obtained from a comparison of the activities of $300 \mu \mathrm{g}(1.02 \mathrm{nmol})$ inhibitor-free acrosin and $5 \mu \mathrm{g}(0.13 \mathrm{nmol})$ trypsin. The former was inactive while the latter decreased the viscosity of gelatin by $50 \%$ in $5.5 \mathrm{~min}$. (A $50 \%$ decrease means a decrease of 0.3 on the vertical scale of a logarithmic plot.)

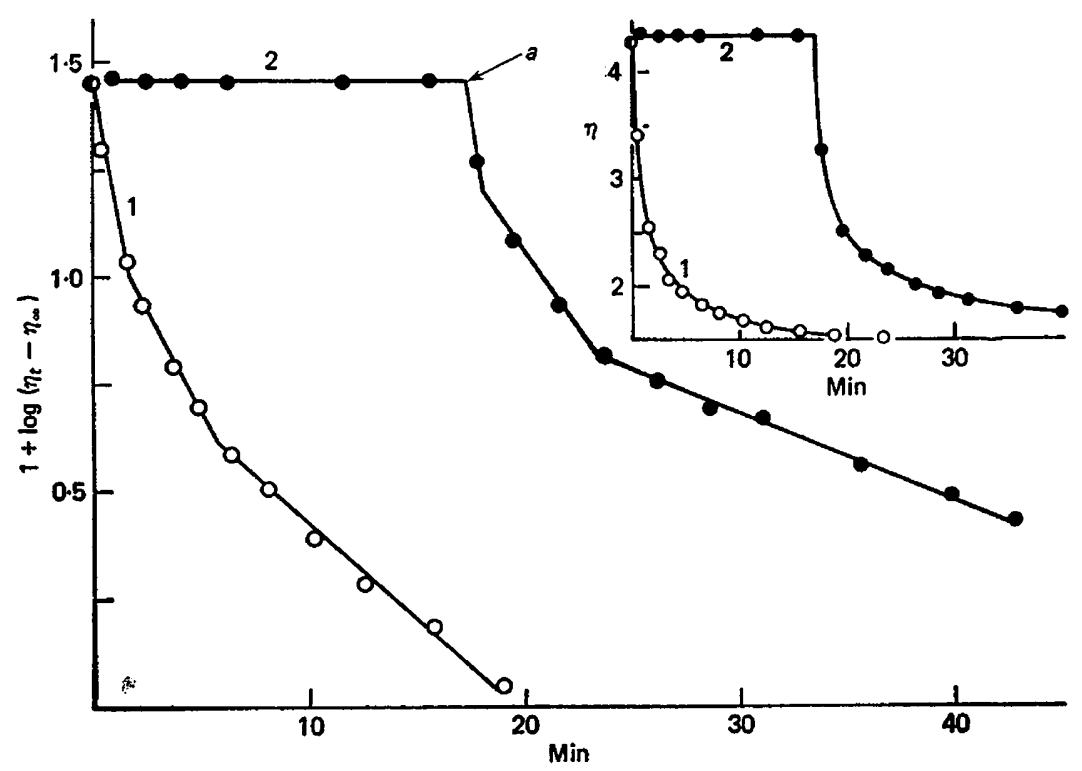

Text-fig. 1. Effects of trypsin and of ram spermatozoa on the viscosity of gelatin solution. Additions to $10 \mathrm{ml}$ of gelatin were: Curve 1,50 $\mathrm{g}$ trypsin (in $10 \mu \mathrm{l}$ ); Curve 2, $0.2 \mathrm{ml}$ frozen-thawed spermatozoa (s.e. $=450$ ) followed at $a$ by $50 \mu$ trypsin. Inset: Curves 1 and 2 plotted as relative viscosity against time. 


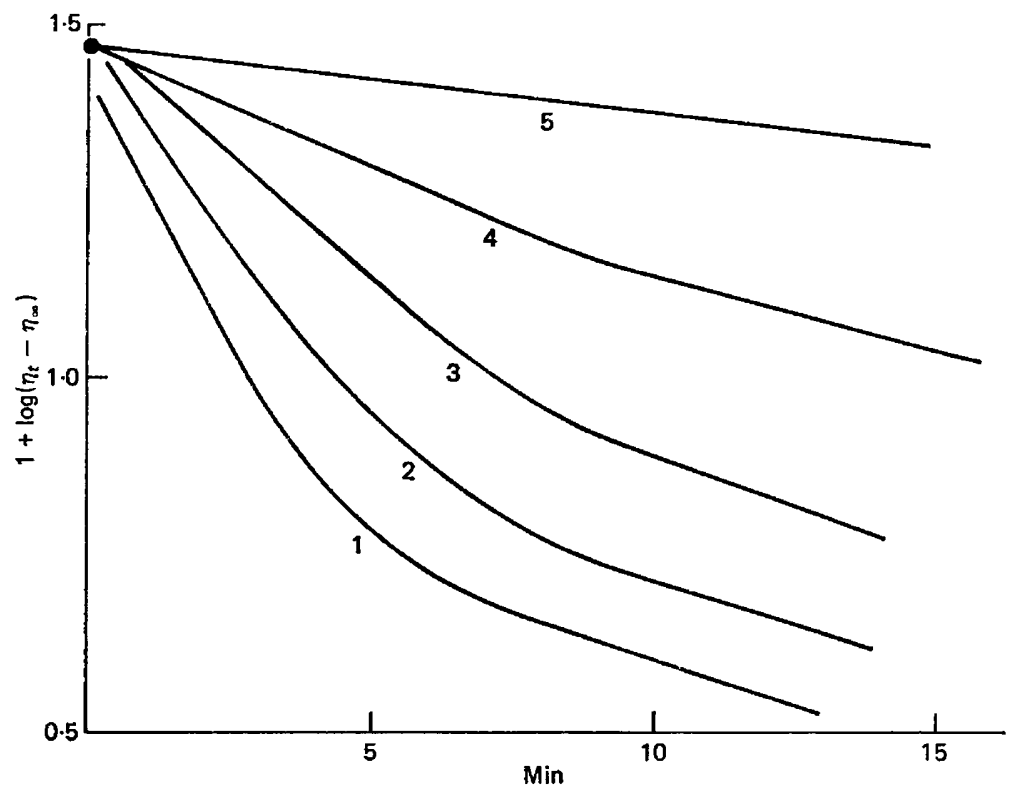

Text-fig. 2. Hydrolysis of gelatin by different quantities of frozen-thawed cock spermatozoa and inhibition by soy-bean inhibitor. Curves 1-4: gelatin with spermatozoa. The s.e. values were for Curve 1, 152; Curve 2, 76; Curve 3, 38; Curves 4 and 5, 23. Curve 5 , as curve 4 but with $40 \mu$ g soy-bean inhibitor.

\section{Degradation of gelatin by frozen-thawed cock spermatozoa: influence of acrosin inhibitors}

In contrast to the preceding results frozen-thawed cock spermatozoa exhibited a strong hydrolytic action on gelatin (Text-fig. 2). The responsible proteinase was less sensitive to soy-bean inhibitor than is trypsin: thus $40 \mu \mathrm{g}$ inhibitor reduced the activity by $70 \%$ (Text-fig. 2). The same degree of inhibition was produced by $20 \mu \mathrm{l}$ cock seminal plasma. The relationship of $k^{\prime}$ to s.e. deviated from linearity when the s.e. exceeded 40 ; thus it was necessary to use low concentrations of spermatozoa to obtain true measures of the effects of inhibitors. Logarithmic plots of viscometric assays of cock sperm fractions showed only two linear regions.

\section{Hydrolysis of $B A E E$ and of gelatin by spermatozoal fractions}

Fractions from cock spermatozoa. Fraction 1, from different batches of semen, showed no acrosin activity when added directly to buffered BAEE but variable activities were detectable in the standard procedure (see 'Materials and Methods'). Further experiments with this fraction are described below. Fraction 1P was inactive. Fraction 2 was always more active, with BAEE, than the parent frozenthawed spermatozoa (Tables 1 and 3 ). In the viscometric assay, however, activities of equivalent amounts of Fraction 2 and of spermatozoa were approximately equal. (For such assays gelatin was dissolved in tris- $\mathrm{HCl}$ and in tris- $\mathrm{HCl}-\mathrm{CaCl}_{2}$.) During the conversion of Fraction 2 to Fraction 3 about $50 \%$ of acrosin activity was lost and the latter became almost completely inactive during storage for 2 days at $5^{\circ} \mathrm{C}$. This decline ran parallel with a decline in activity towards gelatin.

Fractions from ram spermatozoa. Ram acrosin is activated by $\mathrm{Ca}$ ions (Brown et al., 1975a). However, Fraction 2 was inactive in viscometric assays with tris- $\mathrm{HCl}$ buffer and was only feebly active in tris- $\mathrm{HCl}-\mathrm{CaCl}_{2}$. Such activity represented less than $5 \%$ of the activity of an equivalent fraction from cock spermatozoa.

\section{Effects of inhibitors on the hydrolysis of BAEE and of gelatin by cock sperm fractions}

Table 2 shows the effects of inhibitors on the reaction between gelatin and Fraction 3. Ovomucoid exerted only a transient inhibition presumably because it was displaced from the enzyme by gelatin. 
Table 1. Hydrolysis of BAEE by fractions obtained from cock and ram spermatozoa

\begin{tabular}{lc}
\hline & $\mathrm{U} / 10^{9}$ cells \\
\hline Frozen-thawed cock spermatozoa & $3 \cdot 3$ \\
Fraction 2 from cock spermatozoa & $10 \cdot 6$ \\
Denuded ram spermatozoa & $26-29^{*}$ \\
Fraction 2 from denuded ram spermatozoa & 27 \\
Acid extract (pH 2.7) of denuded ram spermatozoa & $27-30^{*}$
\end{tabular}

Fractions were added to buffered BAEE to start the reactions (nonstandard assay).

* Values based on fractionation of five batches of pooled ram semen.

Table 2. Effects of inhibitors of trypsin-like enzymes on the hydrolysis of gelatin by Fraction 3 from cock spermatozoa

\begin{tabular}{lc}
\hline & Relative activity \\
\hline 0.2 ml Fraction $3+10$ ml phosphate-gelatin & {$[100]$} \\
$+25 \mu$ g soy-bean inhibitor & 5 \\
$+12.5 \mu$ g soy-bean inhibitor & 8 \\
$+100 \mu$ cock seminal plasma & 45 \\
$+25 \mu l$ cock seminal plasma & 100 \\
+0.15 mM-p-aminobenzamidine & 11 \\
+0.015 mM- $p$-aminobenzamidine & 89 \\
\hline
\end{tabular}

Relative activities are based on $k^{\prime}$ values for the first linear phases of logarithmic plots.

Table 3. Effects of inhibitors of trypsin-like enzymes on the hydrolysis of BAEE by cock spermatozoa and by Fraction 2 from cock spermatozoa

Additions to standard assay of $50 \mu$ frozen-

thawed cock spermatozoa (s. e. $=35$ )

Relative activity

\begin{tabular}{lc}
\hline $0 \quad(0.42)^{*}$ & {$[100]$} \\
$25 \mu \mathrm{g}$ soy-bean inhibitor & 48 \\
$125 \mu \mathrm{g}$ soy-bean inhibitor & $38 \rightarrow 21 \dagger$ \\
$125 \mu \mathrm{g}$ ovomucoid & 48 \\
$50 \mu \mathrm{g}$ ram acrosomal inhibitor & 33 \\
\hline
\end{tabular}

Additions to standard assay of $50 \mu \mathrm{l}$

Fraction 2 (s.e. $=34)$

$\begin{array}{lr}0 \quad(0.90)^{*} & 100 \\ 62 \cdot 5 \mu \mathrm{g} \text { soy-bean inhibitor } & 14 \\ 1 \mu \mathrm{g} \text { ram acrosomal inhibitor } & 47 \\ 5 \mu \mathrm{g} \text { ram acrosomal inhibitor } & 21 \\ 62.5 \mu \mathrm{g} \text { ovomucoid } & 16 \\ 0.08 \mathrm{mM}-p \text {-aminobenzamidine } & 49 \\ 0.31 \mathrm{mM}-p \text {-aminobenzamidine } & 15\end{array}$

* Units of enzyme activity in absence of inhibitor.

$\dagger$ Activity declined progressively. Quoted values are activities at end of the 1st and 5th min of the assay. 
For comparison, the effects of inhibitors on acrosin activities of cock spermatozoa and Fraction 2 are given in Table 3. This table demonstrates that inhibitors are less effective in experiments with spermatozoa than in experiments with soluble enzyme despite the fact that the $\mathrm{Ca}^{2+}$-containing assay medium causes rapid solubilization of sperm-bound acrosin. The spermatozoa must have considerable non-specific binding capacity for inhibitors.

Portions of cock Fraction 2 (s.e. $=38$ ) were stored overnight with different concentrations of DFP and assayed as in Table 3. Inhibitions of $34 \%$ and $61 \%$ were obtained with 0.2 and 0.4 mM-DFP respectively. Mammalian acrosins show similar high sensitivities to DFP.

\section{Concentrations of acrosin inhibitor in seminal plasma}

Assays of effective molarities of inhibitor yielded the following results: rabbit, 1.3 and $2.4 \mu \mathrm{M}$; ram, 1.7 and $2.3 \mu \mathrm{M}$; cock, $6.1 \mu \mathrm{M}$; bull, $29 \mu \mathrm{M}$; boar, 31 and $34 \mu \mathrm{M}$.

\section{Evidence for an inactive precursor of acrosin in cock spermatozoa}

A property common to all cock Fraction 1 preparations was that, when added to a mixture of BAEE and tris-calcium buffer, they showed very little or no immediate acrosin activity (Table 4, i). However, if they were adjusted to $\mathrm{pH} 8$ with tris-calcium buffer before admixture with buffered BAEE such activity usually developed quite rapidly. In Exp. A this development was complete in 25 min (Table 4, ii). Experiment B was carried out with the same Fraction 1 but it had been stored at $-20^{\circ} \mathrm{C}$ for 2 weeks. It still showed negligible immediate activity when added to buffered BAEE (Table 4, iii) but pretreatment with tris-calcium buffer induced a higher level of activity (Table 4, iv) than in Exp. A. Activity could also be induced if Fraction 1 was stored at $\mathrm{pH} 8$ in the presence of BAEE and $\mathrm{Ca}^{2+}$. Thus the last four lines of Table 4 show the rates of hydrolysis of BAEE at different times during a prolonged acrosin assay.

Three samples of semen were obtained from a different, randomly-bred, group of White Leghorns. From such semen we obtained Fractions 1 that could not be activated and Fractions 2 that were only feebly active. Buruiana (1956) found a wide range of trypsin activities in cock semen.

Table 4. Induction of acrosin activity, measured with BAEE, in low-pH extracts of cock spermatozoa (1) and comparison with activities of tris- $\mathrm{CaCl}_{2}$ extracts (2)

\begin{tabular}{|c|c|c|c|c|c|}
\hline \multirow{2}{*}{\multicolumn{2}{|c|}{ Fraction }} & \multicolumn{2}{|c|}{ Assay system I* } & \multicolumn{2}{|c|}{ Assay system II $\uparrow$} \\
\hline & & $\begin{array}{l}\text { Preincubation } \\
\text { (min) }\end{array}$ & $\begin{array}{c}\text { Activity } \\
\text { (U/mI semen) }\end{array}$ & $\begin{array}{c}\text { Activity } \\
\text { (U/mI semen) }\end{array}$ & $\underset{(\min )}{\mathrm{t}}$ \\
\hline & Frozen-thawed spermatozoa & & & $4 \cdot 0$ & 0 \\
\hline & 2 & & & $7 \cdot 2$ & 0 \\
\hline & 1 & & & 0 (i) & 0 \\
\hline & 1 & 15 & $2 \cdot 6$ & & \\
\hline & 1 & 25 & $3 \cdot 1$ (ii) & & \\
\hline & 1 & 60 & $3 \cdot 1$ & & \\
\hline \multirow[t]{5}{*}{ B. } & 1 & 15 & $5 \cdot 7$ (iv) & & \\
\hline & & & & $(0.2$ (iii) & 0 \\
\hline & $1 \pm$ & & & $1 \cdot 0$ & 2 \\
\hline & 14 & & & 1.6 & 5 \\
\hline & & & & $4 \cdot 1$ & 15 \\
\hline
\end{tabular}

Fractions 1 and 2 were freshly prepared for Exp. A. Surplus Fraction 1 was stored for 14 days at $-20^{\circ} \mathrm{C}$ and used for Exp. B. Roman numerals indicate experimental results that are mentioned in the text.

* As in 'Materials and Methods' except that periods of preincubation were longer.

$\dagger$ Enzyme added to buffered substrate, activity being recorded at time $t$ after the addition. In the final assay ( $\downarrow$ ) rates were measured periodically with a single assay mixture but exhaustion of substrate made necessary a second addition of BAEE after 10 min. 
When the Fraction 2 used for Table 4 had been stored for 1 week at $-20^{\circ} \mathrm{C}$ its acrosin activity increased from $7 \cdot 2$ to $12 \mathrm{mU} / \mathrm{ml}$ semen. If cock spermatozoa were similarly stored frozen, the Fraction 2 prepared from them showed about twice the activity of a Fraction 2 prepared according to the method outlined in Flow-sheet 1 which involves brief freezing.

Attempts to demonstrate re-activation by means of the gelatin assay were unsuccessful. This is because the reaction kinetics are complex and because it is impossible to obtain continuous recordings of viscosity with the Ostwald technique. However, a Fraction 1 that could be re-activated, or was already activated (on the basis of BAEE assays), gave positive results with gelatin while Fraction 1 that could not be re-activated gave negative results.

\section{Discussion}

We conclude that the hydrolyses of gelatin and of BAEE that occur in the presence of cock spermatozoa and of sperm fractions are catalysed by the same enzyme. The two activities are susceptible to the same inhibitors; they have identical patterns of distribution among the different fractions; also, treatments which cause changes in the level of one activity affect the other activity in a comparable manner. Since the inhibitors chosen for this work are established inhibitors of mammalian acrosins the results add further support to the belief that the BAEE-hydrolysing enzyme of cock spermatozoa is acrosin. However, cock acrosin differs from ram acrosin in two respects: only the former catalyses the hydrolysis of gelatin in the assay procedure of Buruiana (1956) and only the latter is stable when suspensions of spermatozoa are acidified to $\mathrm{pH} 2 \cdot 7$.

The inactivity of ram acrosin and ram spermatozoa in viscometric assays is inconsistent with work on the localized lysis of gelatin films by individual spermatozoa (Gaddum \& Blandau, 1970; Gaddum-Rosse \& Blandau, 1972; Benítez-Bribiesca \& Velázquez-Meza, 1972; Penn, Gledhill \& Darżynkiewicz, 1972; Allen, Bishop \& Thompson, 1974; Wendt, Leidl \& Fritz, 1975). Comparison of rates of 'halo' formation by spermatozoa of different animal species with the acrosin activities of detergent extracts (acrosomal fractions) of spermatozoa (Zaneveld et al., 1973) indicates that a rough proportionality exists between the intensity of a halo reaction and the acrosin content of the spermatozoon. Whereas halo growth and halo size should be a measure of enzyme/cell, acrosin activities are given as units/mg detergent-extracted protein. There is lack of agreement on the susceptibility of halo formation to trypsin inhibitors (Penn et al., 1972; Allen et al., 1974; Wendt et al., 1975). Although information on cock and ram spermatozoa is sparse it seems that haloes were formed at similar rates but that final diameters were greater for ram spermatozoa (Allen et al., 1974). In experiments with gelatin films, times taken for haloes to become prominent were usually much greater than the periods (5-15 min) within which cock spermatozoa induce large changes in viscosity. If haloes are accepted as the consequence of acrosin activity, it is difficult to explain why rates of growth of haloes around cock and ram spermatozoa were not very different.

The significance of the very low viscometric activity of a ram Fraction 2 in tris-calcium buffer is uncertain since no activity could be detected in ram acrosin. The same fraction was completely inactive when the gelatin was dissolved in the barbiturate-acetic acid buffer of Gaddum \& Blandau (1970).

The inhibitory actions of seminal plasma upon acrosin and trypsin have been established for a number of species (Fink, Jaumann, Fritz, Ingrisch \& Werle, 1971) although inhibition was expressed in arbitrary units. With the knowledge that the effective molarity of inhibitor in ram seminal plasma is lower than that in cock seminal plasma we suggest that the very different viscometric activities of ram and cock semen are not due to a high concentration of inhibitor in the former.

Loss of cock acrosin activity at low $\mathrm{pH}$ and subsequent recovery after neutralization (Table 4) suggest a reversible modification of the enzyme. We think this unlikely and suggest a reaction mechanism based upon the presence of acrosin and proacrosin in cock spermatozoa. Proacrosin has been isolated from testes and epididymal spermatozoa of the rabbit (Meizel, 1972; Huang-Yang \& Meizel, 1975) and is present also in boar spermatozoa (Polakoski, 1974). The testis proacrosin is more stable than rabbit acrosin in acid solutions and it undergoes rapid autoactivation in the presence of calcium ions at pH 8 (Meizel \& Huang-Yang, 1973). 
Frozen-thawed cock spermatozoa exhibit less than half of the acrosin activity that can be found in Fraction 2. We therefore propose that at least $50 \%$ of the intracellular enzyme occurs as the inactive proacrosin and that when Fraction 1 is prepared the acrosin is irreversibly inactivated while the proacrosin goes into solution. Thus Fraction 2 would contain two acrosin 'pools': the original sperm acrosin and the proacrosin which has been activated by the $\mathrm{Ca}^{2+}$-containing buffer. We further propose that cock spermatozoa contain two types of proacrosin, one of which can be activated by tris-calcium only after storage at $-20^{\circ} \mathrm{C}$. This would explain the apparent increase in proacrosin after a Fraction 1 had been stored at $-20^{\circ} \mathrm{C}$ (Table 4, column 3 ) and also the observed increase in the activity of Fractions 2 that results from storing cock spermatozoa at $-20^{\circ} \mathrm{C}$.

Buruiana (1956) could detect no 'trypsin activity' in the semen of stallion, man, boar, cat, bull and ram. Yet all except cat semen are known to contain acrosin (Zaneveld et al., 1973). Since ram acrosin is inactive against gelatin in the viscometric assay, Buruiana's negative results with ram semen are understandable. Until inhibitor-free acrosins of the other species can be tested viscometrically, it is not possible to assert that lack of activity in Buruiana's assay is characteristic of mammalian acrosins, especially as he detected low trypsin activity in rabbit and dog semen. Buruiana found high trypsin activity in guinea-fowl, drake, turkey and cock semen but none in gander semen. We deduce from this that spermatozoa of the first three species contain what we suggest are typical avian acrosins, i.e. like cock spermatozoa they hydrolyse both BAEE and gelatin.

We greatly appreciate the interest of Dr L. M. Buruiana in this work and we thank him for reprints and for translations of passages in his papers. We also thank Dr S. Meizel for information on his unpublished work, Dr J. C. Boursnell for the loan of apparatus for viscometry and $\mathrm{Mr} \mathrm{B}$. D. Wright for supplies of cock semen.

\section{References}

AllEN, G.J., Bishop, M.W.H. \& Thompson, T.E. (1974) Lysis of photographic emulsions by mammalian and chicken spermatozoa. J. Reprod. Fert. 36, 249252.

Benítez-Bribiesca, L. \& Velázquez-MezA, S. (1972) Cytochemical demonstration of proteolytic activity of human and rat spermatozoa. J. Reprod. Fert. 29, 419-420.

Brown, C.R. \& Hartree, E.F. (1974) Distribution of a trypsin-like proteinase in the ram spermatozoon. J. Reprod. Fert. 36, 195-198.

Brown, C.R., ANdANI, Z. \& Hartree, E.F. (1975a) Studies on ram acrosin. Isolation from spermatozoa, activation by cations and organic solvents, and infuence of cations upon its reaction with inhibitors. Biochem. J. 149, 133-146.

Brown, C.R., ANdani, Z. \& Hartree, E.F. (1975b) Studies on ram acrosin. Fluorimetric titration of operational molarity with 4-methylumbelliferyl p-guanidinobenzoate. Biochem. J. 149, 147-154.

BuruIANA, L.M. (1956) Sur l'activité hyaluronidasique et trypsinique du sperme. Naturwiss. 43, 523.

Buruiană, L.M. \& Niculescu, P. (1957) Cercetări asupra cineticii trypsinei. Studii Cerc. Chim. 5, 558-568.

Buruiană, L.M., Gluhovschi, N., Bilcea, P. \& NĂFORNITÃ, M. (1956) Cercetări asupra activitătii tripsinici a spermei și semificația ei. Studii Cerc. ştint. Baza Timişoara 3, 63-69.

Fink, E., JaUmanN, E., Fritz, H., INgrisch, H. \& Werle, E. (1971) Protease-Inhibitoren im men- schlichen Spermaplasma: Isolierung durch Affinitätschromatographie und Hemmverhalten. HoppeSeyler's Z. physiol. Chem. 352, 1591-1594.

Gaddum, P. \& Blandau, R.J. (1970) Proteolytic reaction of mammalian spermatozoa on gelatin membranes. Science, N.Y. 170, 749-751.

Gaddum-Rosse, P. \& Blandau, R.J. (1972) Comparative studies on the proteolysis of fixed gelatin membranes by mammalian sperm acrosomes. Am. J. Anat. 134, 133-143.

Ho, J.J.L. \& Meizel, S. (1970a) Electrophoretic and biochemical characterization of trypsin-like activity in the spermatozoa of the domestic fowl.J. Cell Biol. 47, 89a.

Ho, J.J.L. \& MeIzeL, S. (1970b) Electrophoretic detection of multiple forms of trypsin-like activity in spermatozoa of the domestic fowl. J. Reprod. Fert. 23, 177179.

Huang-Yang, Y.H.J. \& Meizel, S. (1975) Purification of rabbit testis proacrosin and studies of its active form. Biol. Reprod. 12, 232-238.

Meizel, S. (1972) Biochemical detection and activation of an inactive form of a trypsin-like enzyme in rabbit testes. J. Reprod. Fert. 31, 459-462.

Meizel, S. \& Huang-Yang, Y.H.J. (1973) Further studies of an inactive form of a trypsin-like enzyme in rabbit testes. Biochem. Biophys. Res. Commun. 53, 1145-1150.

NorTHROP, J.H. \& Kunitz, M. (1933) Crystalline trypsin. III. Experimental procedure and method of measuring activity.J. gen. Physiol. 16, 313-321. 
Penn, A., Gledhill, B.L. \& Darżynkiewicz, Z. (1972) Modification of the gelatin substrate procedure for demonstration of acrosomal proteolytic activity. J. Histochem. Cytochem. 20, 499-506.

Polakoski, K.L. (1974) Partial purification and characterization of proacrosin from boar spermatozoa. Fedn Proc. Fedn Am. Socs exp. Biol. 33, 1308 .
Wendt, V., Leidl, W. \& Fritz, H. (1975) The lysis effect of bull spermatozoa on gelatin substrate film. Methodical investigations. Hoppe-Seyler's Z. physiol. Chem. 356, 315-323.

Zaneveld, L.J.D., Polakoski, K.L. \& Williams, W.L. (1973) A proteinase and proteinase inhibitor of mammalian sperm acrosomes. Biol. Reprod. 9, 219-225.

Received 30 April 1975 